\title{
The effect of viscosity and activation mode on biaxial flexure strength and modulus of dual resin cements
}

\author{
Efeito da viscosidade e modo de ativação na resistência flexural \\ biaxial e módulo em cimentos resinosos duais
}

\begin{abstract}
Purpose: The aim of this study was to evaluate the effects of curing mode and viscosity on the biaxial flexural strength (FS) and modulus (FM) of dual resin cements.

Methods: Eight experimental groups were created $(n=12)$ according to the dual-cured resin cements (Nexus 2/Kerr Corp. and Variolink II/lvoclarVivadent), curing modes (dual or selfcure), and viscosities (low and high). Forty-eight cement discs of each product ( $0.5 \mathrm{~mm}$ thick by $6.0 \mathrm{~mm}$ diameter) were fabricated. Half specimens were light - activated for 40 seconds and half were allowed to self-cure. After 10 days, the biaxial flexure test was performed using a universal testing machine $(1.27 \mathrm{~mm} / \mathrm{min}$, Instron 5844). Data were statistically analyzed by three-way ANOVA and Tukey's test (5\%).

Results: Light-activation increased FS and FM of resin cements at both viscosities in comparison with self-curing mode. The high viscosity version of light-activated resin cements exhibited higher FS than low viscosity versions. The viscosity of resin and the type of cement did not influence the FM. Light-activation of dual-polymerizing resin cements provided higher FS and FM for both resin cements and viscosities.

Conclusion: The use of different resin cements with different viscosities may change the biomechanical behavior of these luting materials.
\end{abstract}

Key words: Dual cure resin cement; materials testing; viscosity

\section{Resumo}

Objetivo: O objetivo do estudo é avaliar o efeito do modo de ativação na resistência flexual biaxial (RF) e módulo (MF) em cimentos resinosos duais.

Metodologia: Foram formados oito grupos experientais $(n=12)$ de acordo com cimento resinos (Nexus 2/Kerr Corp. and Variolink II/IvoclarVivadent), modo de ativação (dual ou auto-polimerizado) e viscosidade (baixa e alta). Quarenta e oito discos de cada cimento foram fabridados $(0,5 \mathrm{~mm}$ espessura por 6,0 $\mathrm{mm}$ diametro). Metade dos espécimes foram foto-ativados e a outra metade foi deixado para auto-polimerização. Após dez dias, o teste biaxial foi realizado em máquina de ensaio universal (1,27 mm/min, Instron 5844). Os dados foram analisados estatisticamente por ANOVA e teste Tukey (5\%).

Resultados: A foto-ativação aumentou a RF e RM para os cimentos em ambas as viscosidades em comparação com os grupos auto-polimerizados. A versão alta viscosidade dos cimentos foto-ativados apresentou maior RF que os cimentos em baixa viscosidade. A viscosidade e o tipo de cimento não influenciam o MF. A foto-ativação aumenta os valores de RF e MF para ambos os cimentos e viscosidades.

Conclusão: $\bigcirc$ uso de diferentes cimentos com diferentes viscosidades pode influenciar o comportamento biomecânico de cimentos resinoso.

Palavras-chave: Cimento resinoso dual; teste de material; viscosidade

\author{
Marina Di Francescantonio a \\ Frederick Allen Rueggeberg ${ }^{b}$ \\ Cesar Augusto Galvão Arrais c \\ Glaucia Maria Bovi Ambrosano d \\ Marcelo Giannini e
}

\begin{abstract}
a Graduate Program, Department of Restorative Dentistry, Piracicaba Dental School, State University of Campinas, Piracicaba, SP, Brazil

${ }^{b}$ Department of Oral Rehabilitation, School of Dentistry, Georgia Health Sciences University, Augusta, GA, USA

c Department of Operative Dentistry, School of Dentistry, University of Guarulhos, Guarulhos, SP, Brazil

d Department of Social Dentistry, Piracicaba School of Dentistry, Campinas State University, Piracicaba, SP, Brazil

e Department of Restorative Dentistry, Piracicaba Dental School, State University of Campinas, Piracicaba, SP, Brazil
\end{abstract}

\author{
Correspondence: \\ Marcelo Giannini \\ Department of Restorative Dentistry, \\ Piracicaba Dental School, \\ State University of Campinas \\ Av. Limeira, 901 \\ Piracicaba, SP - Brazil \\ $13414-900$ \\ E-mail: giannini@fop.unicamp.br
}

Received: April 4, 2012

Accepted: June 15, 2012

Conflict of Interests: The authors state that there are no financial and personal conflicts of interest that could have inappropriately influenced their work.

Copyright: (C) 2011 Di Francescantonio et al.; licensee EDIPUCRS. This is an Open Access article distributed under the terms of the Creative Commons Attribution-Noncommercial-No Derivative Works 3.0 Unported License. 


\section{Introduction}

The dual-polymerizing resin cements present characteristics that combine both auto- and light-polymerization to provide cure even in the attenuation of light produced by thickness and opacity of restorations or the absence of light in dark zones at the apical region and deep interproximal areas. Studies have shown that attenuation or absence of light reduces the degree of polymerization for most of the cements (1-3), which can affect some mechanical properties and the solubility of the material. According to Hofmann et al. (4), when the resin cements were lighted-cured the values of flexural strength, modulus and surface hardness were higher than those observed for self-curing without photoactivation groups.

The mechanical properties of resin luting cements are also determined by the type of resin monomers and the content of inorganic particles $(4,5)$. Manufacturers have changed material composition to produce versions of the same commercial product with different viscosities (6). Filled composites are usually highly-viscous materials; however, the resin cements need to present low viscosity, in order to facilitate the cementation of indirect restoration, with minimal thickness of the cement layer (4-7).

The main alteration is observed in the proportion between resin matrix and filler particle content, which results in a low- or high-viscosity material. The manufacturers have indicated these resin cements for specific clinical situations, which are related to marginal and internal fit between the indirect restoration and the dental structure (7). Hahn et al. (6) evaluated the Influence of resin cement viscosity on microleakage of ceramic inlays and recommended highly viscous luting cements for cementing inlays in larger luting spaces.

The practice of fixed prosthodontic has changed with the use of resin cements, which provides resistance to most dental ceramics, standing the occlusal loading without deformation and bonding the indirect restoration to tooth $(8,9)$. The influence viscosity and monomeric conversion of resin cements on physical properties and marginal sealing needs be investigated, in attempt to show the dentists the better luting material for each clinical scenario $(6-10,13)$.

In this study, biaxial flexure strength test was used to evaluate high and low viscosity versions of two resin cements, when they were tested in the dual polymerization (lightand auto- polymerization) and only auto-polymerization modes. The null hypothesis tested was that curing mode and viscosity do not affect flexural strength (FS) and modulus (FM) of resin cements.

\section{Methods}

The compositions of two resin cements tested are presented in Table 1. Two dual-cured resin cements were evaluated in two viscosities: Variolink II High and Low (IvoclarVivadent, Schaan, Liechtenstein) and Nexus 2 High and Low (KerrCo., Orange, CA, USA). The resin cements were manipulated according to manufacturers' instructions in the proportion of 1:1 (catalyst and base paste by volume) and were applied into an elastomeric impression material mold (Aquasil Ultra, Dentsply Caulk, Milford, DE, USA) to create disc-shaped specimens with dimensions of approximately $0.5 \mathrm{~mm}$-thick and $6.0 \mathrm{~mm}$ in diameter. The specimen was covered with a Mylar strip and a microscope glass slide. Manual pressure was applied to force the material to flow into the mold and the excess material was removed after the specimen is removed from the mold. The specimens were either exposed to light for 40 seconds from a halogen light curing unit (XL 3000, 3M ESPE, St. Paul, MN, USA) or were allowed to self-cure. When light-activation was performed, light intensity was constantly monitored with a radiometer (Curing Radiometer Mode 100, Demetron Research Corporation, Danbury, CT, USA) and maintained between 550 and $600 \mathrm{~mW} / \mathrm{cm}^{2}$. Afterwards, specimens were stored at $37^{\circ} \mathrm{C}$ in the dark for 24 hours. Eight experimental groups were created according to product, viscosity, and activation mode, and twelve specimens $(n=12)$ were prepared per group.
Table 1. Compositions of the resin cements used in this study

\begin{tabular}{|c|c|c|}
\hline $\begin{array}{l}\text { Resin cement } \\
\text { (Manufacturer) }\end{array}$ & Composition & $\begin{array}{l}\text { Lote number } \\
\text { (L - low; } \mathrm{H} \text { - high) }\end{array}$ \\
\hline \multirow{2}{*}{$\begin{array}{l}\text { Nexus } 2 \\
\text { (KerrCorp., Orange, } \\
\text { CA, USA) }\end{array}$} & $\begin{array}{l}\text { Base: Bis-GMA, camphoroquinone, barium } \\
\text { aluminoborosilicate glass. }\end{array}$ & \multirow{2}{*}{$\begin{array}{c}438681 \\
452344(\mathrm{~L}) \text { and } \\
452365(\mathrm{H})\end{array}$} \\
\hline & $\begin{array}{l}\text { Catalyst: Bis-GMA, TEGDMA, barium aluminoborosilicate } \\
\text { glass ( } 70 \% \text { byweightand } 53 \% \text { by volume offillersparticles). }\end{array}$ & \\
\hline \multirow{4}{*}{$\begin{array}{l}\text { Variolink II } \\
\text { (IvoclarVivadent, } \\
\text { Schaan, Liechtenstein) }\end{array}$} & $\begin{array}{l}\text { Base: Bis-GMA, urethane dimethacrylate, TEGDMA, } \\
\text { inorganic filler, ytterbium trifluoride, initiator, stabilizer }\end{array}$ & \multirow{4}{*}{$\begin{array}{c}\mathrm{J} 24363 \\
\mathrm{~J} 19103(\mathrm{~L}) \text { and } \\
\mathrm{J} 19730(\mathrm{H})\end{array}$} \\
\hline & $\begin{array}{l}\text { Catalyst: Bis-GMA, urethane dimethacrylate, TEGDMA, } \\
\text { inorganic filler, ytterbium trifluoride, benzoyl peroxide, } \\
\text { stabilizer }\end{array}$ & \\
\hline & $\begin{array}{l}\text { Low-viscosity: } 27.9 \% \text { byweightofmonomersand } 71.2 \% \\
\text { byweightor } 43.6 \% \text { by volume offillersparticles. }\end{array}$ & \\
\hline & $\begin{array}{l}\text { High viscosity: } 22 \% \text { byweightofmonomersand } 77 \% \\
\text { byweightor } 52 \% \text { by volume offillersparticles. }\end{array}$ & \\
\hline
\end{tabular}

Abbreviations: Bis-GMA: bisphenol-A-diglycidyletherdimethacrylate; TEGDMA: triethylene glycol dimethacrylate. 
The discs were individually placed into a custommade testing jig and tested for biaxial flexure strength on a universal testing machine (Instron 5844, Instron Corp, Canton, MA, USA) at $1.27 \mathrm{~mm} / \mathrm{min}$ until failure occurred (14). The maximum load was recorded for each specimen and the elastic modulus was determined from the linear portion of each stress/strain curve. Formula for biaxial flexural strength $(\sigma)$ :

$$
\sigma=-0.238 * \frac{7 P(X-Y)}{b^{2}},
$$

where:

$\sigma$ is the maximum center tensile stress (megapascals);

$P$ is the total load causing fracture (Newtons);

$X=(1+v) \ln \left(\mathrm{r}_{2} / \mathrm{r}_{3}\right)^{2}+[(1-v) / 2]\left(\mathrm{r}_{2} / \mathrm{r}_{3}\right)^{2} ;$

$Y=(1+v)\left[1+\ln \left(\mathrm{r}_{1} / \mathrm{r}_{3}\right)^{2}\right]+\left[(1-v)\left(\mathrm{r}_{1} / \mathrm{r}_{3}\right)^{2}\right.$;

$b$ is the specimen thickness at fracture origin (millimeters);

in which:

$v$ is Poisson's ratio (used $v=0.25$ );

$\mathrm{r}_{1}$ is radius of support circle (millimeters);

$\mathrm{r}_{2}$ is radius of loaded area (millimeters);

$\mathrm{r}_{3}$ is radius of specimen (millimeters).

Flexural strength (FS) and modulus (FM) were calculated by SRS Biaxial Testing Software (Instron Corp., Canton, MA, USA). FS and FM data were normal and homocedastic. They were analyzed by three-way (viscosity, resin cement, and polymerization mode factors) analysis of variance (ANOVA) and Tukey's post-hoc test (pre-set alpha of 0.05).

\section{Results}

Mean FS and FM values are presented in Tables 2 and 3, respectively. For FS analysis (Table 2), three-way ANOVA revealed statistically significant differences for the factors "viscosity" $(P=0.0272)$ and "polymerization mode" $(P<0.0001)$. No significant difference was revealed for the factor "resin cement" $(P=0.5020)$. The double interaction "viscosity" $\times$ "polymerization mode" was also statistically significant $(P=0.05)$. For the FM analysis (Table 3 ), threeway ANOVA revealed no statistically significant differences for the factors "viscosity" $(P=0.4790)$ and "resin cement" $(P=0.6197)$. However, it was observed significant difference for the factor "polymerization mode" $(P<0.0001)$. No double or triple interaction among factors were significant $(P>0.05)$.

Light-activation increased FS $(134.7 \pm 27.4 \mathrm{MPa}$ for Nexus 2/low viscosity; $146.9 \pm 18.6 \mathrm{MPa}$ for Nexus $2 /$ high viscosity; $137.6 \pm 22.1 \mathrm{MPa}$ for Variolink II/low viscosity and 159.0 $22.0 \mathrm{MPaVariolink}$ II/high viscosity) and $\mathrm{FM}$ values (7.2 $\pm 2.1 \mathrm{GPa}$ for Nexus 2/low viscosity; $7.6 \pm 1.4 \mathrm{GPa}$ for Nexus 2/high viscosity; 7.1 $\pm 1.5 \mathrm{GPa}$ for Variolink II/low viscosity and 7.6 $\pm 2.0 \mathrm{GPaVariolink}$ II/high viscosity) for both resin cements and in both viscosities $(P<0.05)$. The high viscosityversion of resin cements presented higher FS than low-viscosity version only in light-activated groups $(P<0.05)$. The self-curing mode of resin cements resulted in similar FS when resin cements with low viscosity $(120.9 \pm 11.0 \mathrm{MPa}$ for Nexus 2 and $117.1 \pm 24.3 \mathrm{MPa}$ for Variolink II) were compared to those with high viscosity $(120.2 \pm 20.5 \mathrm{MPa}$ for Nexus 2 and $120.0 \pm 12.0 \mathrm{MPa}$ for Variolink II) $(P>0.05)$. The FMwas not influenced by type of resin cement and its viscosities (Low viscosity: 7.2 \pm 2.1 GPa for Nexus 2/Light-activated; 5.5 $\pm 8.6 \mathrm{GPa}$ for Nexus 2/ Self-cured; 7.1 $\pm 1.5 \mathrm{GPa}$ for Variolink II/Light-activated; $5.4 \pm 8.9 \mathrm{GPa}$ for Variolink II/Self-cured and High viscosity: 7.6 $\pm 1.4 \mathrm{GPa}$ for Nexus 2/Light-activated; $5.6 \pm 1.9 \mathrm{GPa}$ for Nexus 2/Self-cured;7.6 $\pm 2.0 \mathrm{GPa}$ for Variolink II/Lightactivated; $5.3 \pm 9.2$ for Variolink II/Self-cured) $(P>0.05)$.

\section{Discussion}

The results showed that the dual-polymerizing mode (light-activating plus self-curing) led to higher FS and FM than self-curing mode alone. Moreover, the viscosity

Table 2. Means values (SD) of flexural strength (MPa)

\begin{tabular}{lllll}
\hline \multirow{2}{*}{ Viscosity } & \multicolumn{3}{c}{ Nexus 2 } & \multicolumn{3}{c}{ Variolink II } \\
\cline { 2 - 6 } & Light-activated & Self-cured & Light-activated & Self-cured \\
\hline Low & $134.7(27.4) \mathrm{Ab}$ & $120.9(11.0) \mathrm{Ba}$ & $137.6(22.1) \mathrm{Ab}$ & $117.1(24.3) \mathrm{Ba}$ \\
High & $146.9(18.6) \mathrm{Aa}$ & $120.2(20.5) \mathrm{Ba}$ & $159.0(22.0) \mathrm{Aa}$ & $120.0(12.0) \mathrm{Ba}$ \\
\hline
\end{tabular}

Means having similar letters (lower case within column; upper case within row) are not significantly different.

Table 3. Means values (SD) of flexural modulus (GPa)

\begin{tabular}{lcccc}
\hline \multirow{2}{*}{ Cement } & \multicolumn{2}{c}{ Low viscosity } & \multicolumn{2}{c}{ High viscosity } \\
\cline { 2 - 5 } & Light-activated & Self-cured & Light-activated & Self-cured \\
\hline Nexus 2 & $7.2(2.1) \mathrm{Aa}$ & $5.5(8.6) \mathrm{Ba}$ & $7.6(1.4) \mathrm{Aa}$ & $5.6(1.9) \mathrm{Ba}$ \\
Variolink II & $7.1(1.5) \mathrm{Aa}$ & $5.4(8.9) \mathrm{Ba}$ & $7.6(2.0) \mathrm{Aa}$ & $5.3(9.2) \mathrm{Ba}$ \\
\hline
\end{tabular}

Means having similar letters (lower case within column; upper case within row) are not significantly different. 
affected FS values for both resin cements in light-activated groups with no influence on FM. Hence, the null hypothesis that curing mode does not affect FS and FM of resin cements was rejected, while the null hypothesis that viscosity does not affect FM was accepted.

Light-activation combined with chemical polymerization in dual-curing resin cements reduces the quantity of remaining double bonds, which increases the monomeric conversion of the material and consequently the hardness of the resin cement (15). Studies have demonstrated that only the chemical polymerization of dual-cured resin cements was not enough to promote hardness $(16,17)$ and degree of conversion values $(1,3)$ as high as those obtained with the light-activation.

Clinically, the light intensity reaching the resin cement is strongly attenuated by the distance from the light source, absorbing characteristics of the indirect restorative material or during post cementation. This attenuation may result in low degree of conversion if self-curing components would not be capable of promoting proper polymerization in the absence of light. El-Mowafy and Rubo (18) and Hofmann et al. (4) found that the self-curing components of most dual-cured resin cements were not capable of compensating the light attenuation and reported reduction in hardness and flexural strength values. In this study, the chemical curing mechanism alone resulted in lower FS and FM than the light-activated reaction when dual-cured resin cements were used.

For Nexus 2 (Kerr Corp.) and Variolink II (Ivoclar Vivadent), the cement viscosity changes with the use of a catalyst paste (high or low). The manufacturer of Variolink II has informed the percentage of the monomeric components and filler content: the catalyst fluid (low viscosity) paste contains $27.9 \%$ by weight of monomers and $71.2 \%$ by weight or $43.6 \%$ by volume of fillers particles. The dense catalyst (high viscosity) presents $22 \%$ by weight of monomers and $77 \%$ by weight and $52 \%$ by volume of fillers particles, indicating that the changing of their monomeric and inorganic composition is significant. The manufacturer of Nexus 2 resin cement does not supply these data and only shows in average, $70 \%$ by weight and $53 \%$ by volume of fillers particles, not specifying the viscosities.

Milleding et al. (12) demonstrated that specimens made with high-viscosity materials had a significantly higher microhardness compared to those made with low-viscosity materials. On the other hand, Ferrari et al. (13) showed that higherfiller content increased polymerization stress in luting cements, decreased push-out bond strength, and increased interfacial nanoleakage expression. In this study, when the resin cements were light-activated, the high viscosity materials exhibited higher FS than low viscosity versions. In the self-curing mode, no difference on FS was observed when comparing the viscosities and products. Also, the FM was not influence neither by the viscosity nor the products. Thus, the increasing for the concentration of filler particles (barium aluminoborosilicate glass, ytterbium trifluoride and other inorganic fillers) in approximately $16 \%$ by volume and the light-activation mode led to FS increasing for both resin cements.

The light-activation of the dual-cured cements showed essential in order to ensure high FM and, along with that, better mechanical properties, in the same way that happens with FS. When the increase in viscosity did not affect FM and FS, similar results were observed because the hardness provided by the polymerization of the monomers was enough to compensate the reduction of the inorganic content of the low-viscosity cement.

The flexural strength is a mechanical property that shows the maximum stress before fracture. If the load exceeds the maximum value of flexural strength of the cement, it can fracture and compromise the durability of the indirect restoration $(9,19,20)$. The biaxial test provided another data about an important property related to the clinical behavior of the dental materials. This property is called flexural modulus, which is the ratio between stress and strain in the elastic regimen, in other words, how much stress is necessary to deform the material before the proportional limit $(9,21)$. In this study, the FM did not differ between the resin cements, similar to what happened with the FS. Also, no statistical difference in FM was observed between high and low viscosities. However, when the cements were dual polymerized (light-cured), the FM average values were 20\% higher than those observed in auto polymerized cements (Tables 2 and 3).

Authors have suggested that an intermediate FM value is important in order to prevent microinfiltration (21) and transferring stress from the loaded restoration to the underlying tooth structure (22). The intermediate FM values should be between the dentin value that is around $18 \mathrm{GPa}$ and the indirect restoration, which varies according to the type of the material used (9). The FM of the metal alloy restoration is between 88 and $220 \mathrm{GPa}$, while for ceramic restorations is around 55 and $236 \mathrm{GPa}(9)$. Thus, the results of the FM for the resin cements tested in this study were lower than the dentin and the restorative materials, however, other properties of these luting materials have been considered for cementation of indirect restorations $(11,22-25)$.

\section{Conclusions}

In conclusion, the results suggested that the lightactivation of dual resin cements, independently from their viscosity, may improve the biomechanical features (FS and FM) of these luting materials. The high viscosity version of light-activated resin cements produced higher FS than those observed in low viscosity versions. The viscosity and the type of resin cement did not influence the FM.

\section{Acknowledgement}

Supported by FAPESP (\#06/58813-3), CNPq (\#3057772010-6) and FAEPEX-UNICAMP (\#396/07). 
1. Arrais CA, Rueggeberg FA, Waller JL, de Goes MF, Giannini M. Effect of curing mode on the polymerization characteristics of dual-cured resin cement systems. J Dent 2008;36:418-26.

2. Arrais CA, Giannini M, Rueggeberg FA. Effect of sodium sulfinate salts on the polymerization characteristics of dual-cured resin cement systems exposed to attenuated light-activation. J Dent 2009;37:219-27.

3. Arrais CA, Giannini M, Rueggeberg FA. Kinetic analysis of monomer conversion in auto- and dual- polymerizing modes of commercial resin luting cements. J Prosthet Dent $2009 ; 101: 128-36$

4. Hofmann N, Papsthart G, Hugo B, Klaiber B. Comparison of photo-activation versus chemical or dual-curing of resin-based luting cements regarding flexural strength, modulus and surface hardness. J Oral Rehabil $2001 ; 28: 1022-8$.

5. Kawano F, Ohguri T, Ichikawa T, Matsumoto N. Influence of thermal cycles in water on flexural strength of laboratory-processed composite resin. J Oral Rehabil 2001 ;28:703-7.

6. Hahn P, AttinT, Gröfke M, Hellwing E. Influence of resin cement viscosity on microleakage of ceramic inlays. Dent Mater 2001;17:191-6.

7. Neves AD, Discacciati JA, Orêfice RL, Jansen WC. Correlation between degree of conversion, microhardness and inorganic content in composites. Braz Oral Res 2002; 16:349-54.

8. Kamposiora P, Papavasilious G, Bayne SC, Felton DA. Finite element analysis estimates of cement microfracture under complete veneer crowns. J Prosthet Dent 1997;71:435-41.

9. Li ZC, White SN. Mechanical properties of dental luting cements. J Prosthet Dent 1999;81:597-609.

10. Blackman R, Barghi N, Duke E. Influence of ceramic thickness on the polymerization of light-cured resin cement. J Prosthet Dent 1990;63:295-300.

11. Rosenstiel SF, Land MF, Crispin BJ. Dental luting agents: A review of the current literature. J Prosthet Dent 1998;80:280-301.

12. Milleding P, Ahlgren F, Wennerberg A, Ortengren U, Karlsson S. Microhardness and surface topography of a composite resin cement after water storage. Int J Prosthodont $1998 ; 11: 21-6$.

13. Ferrari M, Carvalho CA, Goracci C, Antoniolli F, Mazzoni A, Mazzotti G, Cadenaro $M$, Breschi L. Influence of luting material filler content on post cementation. J Dent Res 2009;88:951-6.

14. Giannini M, Mettenburg D, Arrais CAG, Rueggeberg FA. Effect of filler addition on biaxial flexural strength and modulus of commercial dentin bonding systems. Quintessence Int $2011 ; 42: 39-43$

15. Sigemori RM, Reis AF, Giannini M, Paulillo LA. Curing depth of a resin-modified glass ionomer and two resin-based luting agents. OperDent 2005;30:185-9.

16. Peutzfeldt A. Dual-cure resin cements: in vitro wear and effect of quantity of remaining double bonds, filler volume, and light curing. Acta Odontol Scand 1995;53:29-34

17. El-Mowafy OM, Rubo MH, El-Badrawy WA. Hardening of new resin cements cured through a ceramic inlay. Oper Dent 1999;24:38-44.

18. El-Mowafy OM, Rubo MH. Influence of composite inlay/onlay thickness on hardening of dual-cured resin cements. J Can Dent Assoc 2000;66:147.

19. Attar N, Tam LE, McComb D. Mechanical and physical properties of contemporary dental luting agents. J Prosthet Dent 2003;89:127-34.

20. Saskalauskaite E, Tam LE, McComb D. Flexural strength, elastic modulus, and pH profile of self-etch resin luting cements. J Prosthodont 2008;17:262-8.

21. Platt JA. Resin cements: into the 21 st century. Compend Contin Educ Dent 1999;20: 1173-6.

22. Diaz-Arnold AM, Vargas MA, Haselton DR. Current status of luting agents for fixed prosthodontics. J Prosthet Dent 1999;81:135-41.

23. Santos-Daroz CB, Oliveira MT, De Goes MF, Nikaido T, Tagami J, Giannini M. Bond strength of a resin cement to dentin using the resin coating technique. Braz Oral Res 2008;22:198-204.

24. Bonfante G, Kaizer OB, Pegoraro LF, Valle AL. Tensile bond strength of glass fiber posts luted with different cements. Braz Oral Res 2007;21:159-64.

25. França FA, Oliveira M, Rodrigues JÁ, Arrais CAG. Pre-heated dual-cured resin cements: analysis of the degree of conversion and ultimate tensile strength. Braz Oral Res $2011 ; 25: 174-9$ 